\title{
Jetzt anmelden!
}

Alle weiteren Informationen unter www.oerg.at/oerg2013
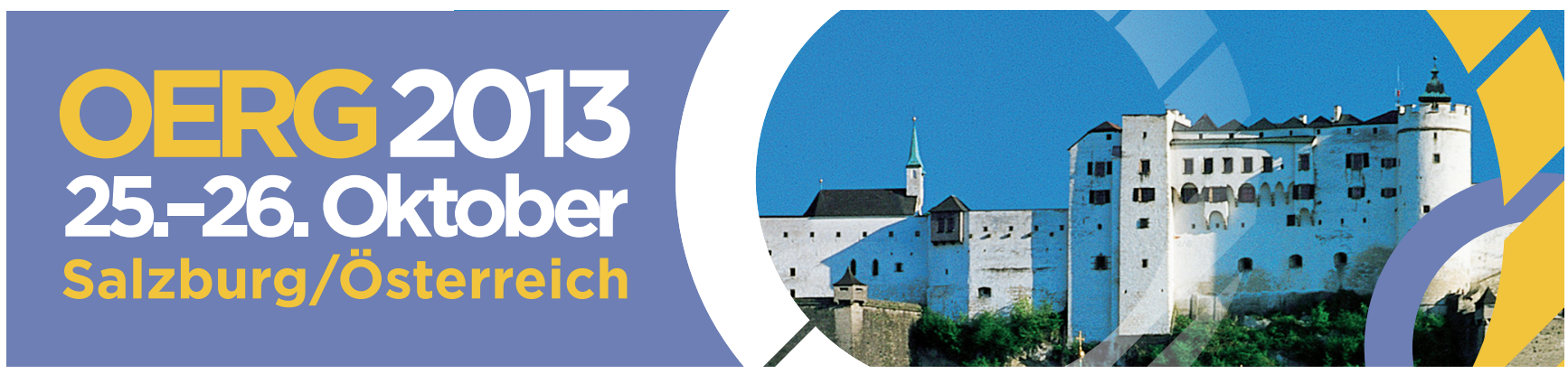